\title{
A NEWLY DISCOVERED ROLE FOR COWPER'S GLAND SECRETION IN RODENT SEMEN COAGULATION
}

\author{
R. G. HART* AND J. S. GREENSTEIN \\ Department of Biological Sciences, Duquesne University, Pittsburgh, \\ Pennsylvania
}

(Received 26th September 1967)

\begin{abstract}
Summary. When rat Cowper's (bulbo-urethral) secretion was reacted in vitro with vesicular secretion, coagulation occurred. The reaction displayed a $\mathrm{pH}$ optimum of 5.9. Neither heat nor dialysis of Cowper's secretion destroyed its activity. Electrophoretic fractionation of Cowper's secretion resulted in the isolation of the active fraction which, on the basis of chemical tests, appears to be a glycoprotein. The vesicular substrate for this reaction was identified by electrophoresis.

Cowper's secretion of the mouse and hamster was also active in coagulating vesicular secretion, but this gland, in the guinea-pig, was without activity. Electrophoresis of bulbo-urethral secretion demonstrated that the guinea-pig alone lacked the fraction which corresponded to the active agent in the rat.

The results indicate that the secretion of the bulbo-urethral glands in the rat, mouse and hamster (but not the guinea-pig) may have a hitherto unrecognized role in the formation of the copulatory plug and subsequent fertility in these species.
\end{abstract}

\section{INTRODUCTION}

It was first recognized in the latter part of the last century that the agent responsible for the initiation of semen coagulation in the rat and guinea-pig is a secretory product of prostatic origin and was subsequently termed vesiculase (Gamus \& Gley, 1899). A more extensive investigation of this problem by Walker (1910) demonstrated that this enzyme is secreted by the anterior prostate or coagulating gland. Vesiculase is a heat-labile protein which reacts with seminal vesicle secretion to produce a coagulant (Gotterer, Ginsburg, Schulman, Banks \& Williams-Ashman, 1955). The enzyme has an optimum $\mathrm{pH}$ of 7.4 (Gotterer et al., 1955) and its reaction with vesicular secretion is inhibited by metal chelating agents such as versene (Gotterer \& WilliamsAshman, 1957).

The first indication that the coagulation reaction was diphasic in nature was presented by Gotterer \& Williams-Ashman (1957). This observation was promptly confirmed by Zorgniotti \& Brendler (1958). Subsequent studies by Speyer (1959) resulted in the discovery of coagulase, a heat-labile protein that

* Present address : Department of Biology, Slippery Rock State College, Slippery Rock, Pennsylvania. 
initiates the reaction by which coagulinogen, secreted by the seminal vesicles, forms the coagulated protein. Vesiculase converts vesicular procoagulase to coagulase. Procoagulase is heat-labile and its conversion to coagulase can be inhibited by versene.

This paper presents the results of experiments which provide new evidence that Cowper's secretion in the rat, mouse and hamster is also able to coagulate vesicular secretion in vitro.

\section{MATERIALS AND METHODS}

Preparation of male accessory gland secretions

Fresh secretions from the male accessory glands were obtained from mature rats, hamsters, mice and guinea-pigs by milking the excised glands immediately into a phosphate-buffered solution containing $7 \mu \mathrm{moles} \mathrm{NaCl} / \mathrm{ml}$. The solutions containing prostatic, coagulating and vesicular secretions were buffered at $\mathrm{pH}$ 7.4 whereas, unless otherwise stated, solutions of bulbo-urethral secretion were buffered at $\mathrm{pH} \mathrm{5.9}$. The solutions for the in vitro studies were standardized to contain $10 \mathrm{mg} / \mathrm{ml}$ of vesicular protein, $0.4 \mathrm{mg} / \mathrm{ml} \mathrm{bulbo-urethral} \mathrm{protein} \mathrm{and}$ $0.5 \mathrm{mg} / \mathrm{ml}$ of coagulating protein. Protein concentration was determined spectrophotometrically (Warburg \& Christian, 1941). The solutions before quantitation were clarified by centrifugation at $3000 \mathrm{~g}$ for $20 \mathrm{~min}$.

\section{Measurement of coagulation}

Coagulation was measured by turbidity determinations at $660 \mathrm{~m} \mu$ (Gotterer et al., 1955) with a Spectronic 20 according to the following procedure. $1.8 \mathrm{ml}$ of vesicular secretion was reacted with $0.8 \mathrm{ml}$ of either Cowper's or coagulating secretion at $37^{\circ} \mathrm{C}$. At 5- to 10 -min intervals over a 40 - to 70 -min time period turbidity readings were made against a blank containing a vesicular secretion.

\section{Paper electrophoresis}

Paper electrophoresis was carried out in a Durrum cell for $16 \mathrm{hr}$ at a constant voltage (100 volts) employing a barbiturate buffer of $\mathrm{pH} 8.6$ with an ionic strength of 0.075 . Following electrophoresis the paper strips were stained with bromo-phenol blue. Optical density measurements were made on each reacting fraction by eluting the fractions separately into $4 \mathrm{ml}$ of $0.5 \%$ sodium carbonate and measuring the absorbance at $590 \mathrm{~m} \mu$ with a Spectronic 20.

\section{RESULTS}

When the male accessory secretions of the rat were reacted in vitro in all possible combinations only two mixtures produced a coagulant: (1) seminal vesicle + coagulating gland; (2) seminal vesicle + Cowper's gland secretions (Text-fig. 1) Varying the $\mathrm{pH}$ of the reaction of the latter mixture between $\mathrm{pH} 1.0$ and $\mathrm{pH}$ 14.0 yielded an optimum $\mathrm{pH}$ of 5.9 for the reaction. Heating Cowper's secretion at $100^{\circ} \mathrm{C}$ for $15 \mathrm{~min}$ had no effect on its activity nor did dialysis for $24 \mathrm{hr}$ at $4^{\circ} \mathrm{C}$. Chromatography of Cowper's secretion on Sephadex G-75 resulted in the elution of the active agent in the void column. Acid hydrolysis $(8 \mathrm{~N}-\mathrm{HCl}, 9 \mathrm{hr}$, 


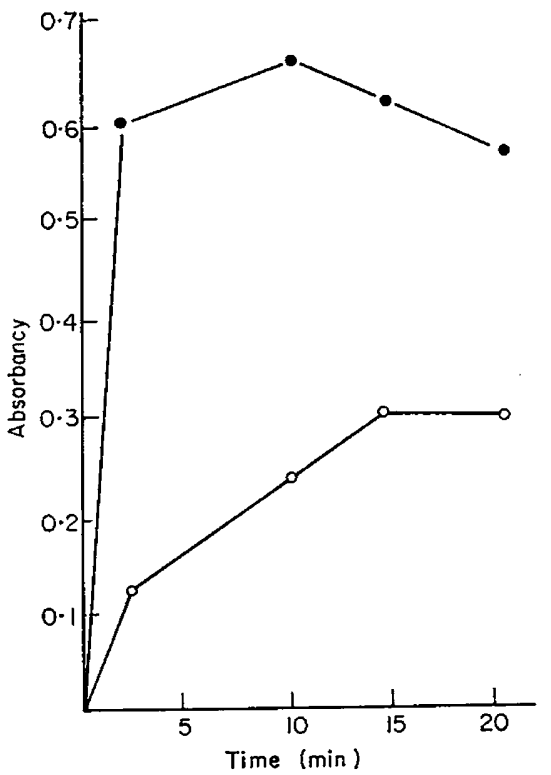

TEXT-FIG. 1. The influence of Cowper's secretion $(0.4 \mathrm{mg}$ protein $/ \mathrm{ml})(\bullet)$ and coagulating gland secretion $(0.5 \mathrm{mg}$ protein $/ \mathrm{ml})(0)$ on the coagulation of vesicular secretion $(10 \mathrm{mg}$ protein $/ \mathrm{ml}$ ) in the rat.
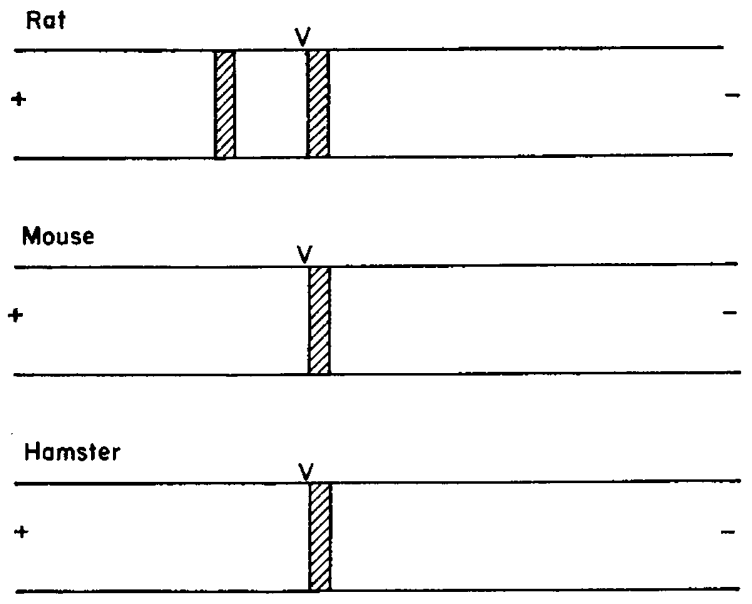

$$
\text { Guineo-pig }
$$

$\checkmark$

$+$

TexT-Ric. 2. Typical electrophoretic fractionation profile of Cowper's secretion from the rat, mouse, hamster and guinea-pig. Fraction 2 (rat only) has been designated as that molecular species which moves toward the anode, whereas the fraction nearest the origin (V) has been designated Fraction 1. 
$100^{\circ} \mathrm{C}$ ) of Cowper's secretion and subsequent neutralization to $\mathrm{pH} 5.9$ caused a loss of all activity.

Paper electrophoresis of Cowper's secretion from the rat resulted in the separation of two bromo-phenol blue positive fractions (Text-fig. 2). Fraction 1 displayed little migratory movement at a $\mathrm{pH} 8 \cdot 6$, whereas a faintly staining Fraction 2 moved toward the anode. When Fractions 1 and 2 were eluted individually into a phosphate buffer, $\mathrm{pH} 5 \cdot 9$, and reacted with seminal vesicle secretion, only Fraction 1 produced a coagulation. In each reaction the protein concentration of the fractions from Cowper's secretion $(0.1 \mathrm{mg}$ protein $/ \mathrm{ml})$ and the vesicular substrate $(10 \mathrm{mg}$ protein $/ \mathrm{ml}$ ) were identical. Moreover, by adding
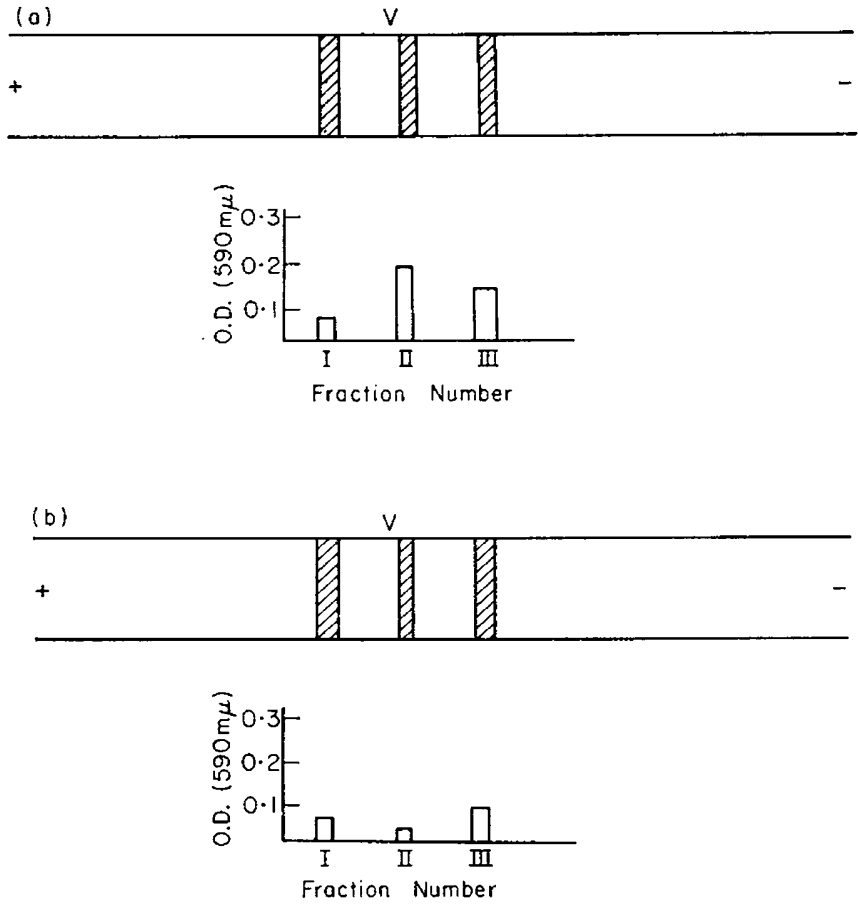

TExT-FIG. 3. (a) Typical electrophoretic fractionation profile of the proteins from the seminal vesicle of the rat with the absorbancy (O.D.) of each band indicated by the histogram. (b) Same as (a) except that before electrophoresis the vesicular substrate was reacted with Fraction 1 from Cowper's secretion. $V$ indicates the origin.

Fraction 1 to Fraction 2 and then reacting the combination with vesicular substrate no greater degree of coagulation was observed. The initiation of coagulation by Fraction 1 was, however, less than would be expected from a homogeneous preparation. This suggests that in the process of electrophoresis some of the activity was lost by denaturation.

To gain some insight into the chemical nature of the active molecule in bulbo-urethral secretion, Fraction 1 was subjected to various chemical assays. This fraction, when reacted with the orcinol reagent (Long \& Staples, 1959), produced a violet colour which had an absorption spectrum identical to that of a sialic acid standard. Fraction 1 produced a blue colour with the biuret 
reagent (Mehl, 1945) and a yellow colour with the cysteine reagent (Dische, 1955) suggesting the presence of hexose in the molecule.

Text-fig. 3(a) illustrates the results of an electrophoretic fractionation of rat vesicular secretion. It was possible by this method to separate three welldefined fractions. Fraction I migrated toward the anode, whereas Fractions II and III, listed numerically in order of migration, displayed a movement toward the cathode. To determine the particular vesicular protein substrate of Fraction 1 from Cowper's secretion the optical densities of Fractions I, II and III were determined in a standard sample $(0.008 \mathrm{ml}$ containing $10 \mathrm{mg}$ vesicular protein $/ \mathrm{ml}$ ) separated electrophoretically, as described previously. Fraction 1 of Cowper's secretion was then reacted with vesicular secretion $(10 \mathrm{mg} / \mathrm{ml})$, the coagulant removed by centrifugation and a sample of the reaction fluid $(0.008 \mathrm{ml})$ fractionated electrophoretically. The optical densities of Fractions I, II and III were determined and compared to that of the standard. Text-fig. 3(b) demonstrates that the only fraction substantially reduced when reacted with Fraction 1 of Cowper's secretion was the vesicular Fraction II.

TABLE 1

THE EFFECT OF GROSS REACTING COWPER'S AND GOAGULATING SECRETION WITH VESICULAR SUBSTRATE IN THE RAT, MOUSE, HAMSTER AND GUINEA-PIG

\begin{tabular}{l|c|c|c|c|c|c|c|c}
\hline $\begin{array}{c}\text { Seminal } \\
\text { vesicle } \\
\text { substrate }\end{array}$ & \multicolumn{2}{|c|}{ Rat } & \multicolumn{2}{|c|}{ Mouse } & \multicolumn{2}{c|}{ Hamster } & \multicolumn{2}{c}{ Guinea-pig } \\
\cline { 2 - 8 } & Cowper's & Coagulating & Cowper's & Coagulating & Cowper's & Coagulating & Cowper's & Coagulating \\
\hline Rat & + & + & + & + & + & + & - & + \\
Mouse & + & + & + & + & + & + & - & + \\
Hamster & + & + & + & + & + & + & - & + \\
Guinea-pig & \pm & + & - & + & - & + & - & + \\
\hline
\end{tabular}

' + ' indicates coagulation, ' - ' indicates no coagulation and ' \pm ' indicates slight coagulation.

The results of cross reacting all possible combinations of bulbo-urethral and coagulating secretion with vesicular secretion among rats, mice, hamsters and guinea-pigs are shown in Table 1. Coagulating secretion was effective in initiating vesicular coagulation in each species regardless of the source of enzyme or substrate, whereas Cowper's secretion in the guinea-pig was inactive when reacted with seminal vesicle secretion of each of the species studied. Moreover, Cowper's secretion from the mouse and hamster was unable to coagulate vesicular secretion from the guinea-pig. All other combinations studied produced a coagulation reaction.

The possible basis of the species differences observed in the activity of Cowper's secretion was investigated by comparing the electrophoretic properties of Cowper's secretion from these species. Text-fig. 2 illustrates that a fraction corresponding in electrophoretic mobility to Fraction 1 in the rat was present in Cowper's secretion from the mouse and hamster. Fraction 2, however, was absent in each of these latter species, and in the guinea-pig neither fraction was present. Since Fraction 1 has been demonstrated to be the active fraction in the rat promoting vesicular coagulation it is reasonable to assume that Cowper's 
secretion in the guinea-pig is devoid of activity because Fraction 1 is lacking. This does not explain why Cowper's secretion in the rat, mouse and hamster was only slightly effective or completely non-effective in promoting coagulation of vesicular secretion from the guinea-pig. Text-fig. 4 shows that the electrophoretic fractionation patterns of rat, mouse and hamster vesicular secretions were identical, but that in the case of the guinea-pig the fractionation pattern was distinctly different. The fraction corresponding to Fraction II in the rat was either entirely absent or present in a very low concentration. Thus, the
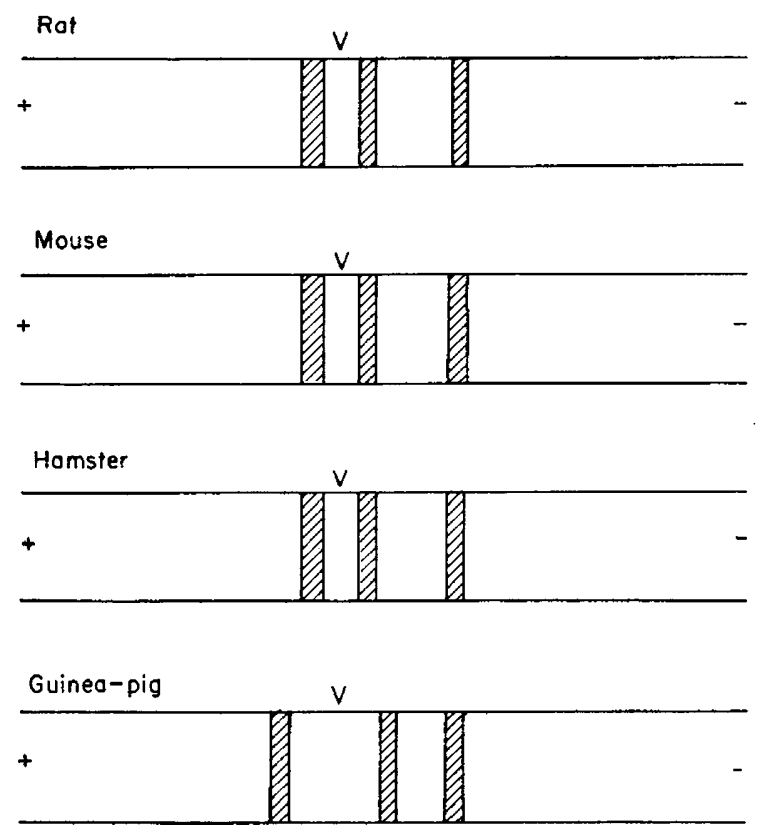

TexT-FIG. 4. Electrophoretic patterns of seminal vesicular secretion from rat, mouse, hamster and guinea-pig.

apparent reason for the failure of vesicular secretion in the guinea-pig to react with Cowper's secretion of the other species was a marked reduction or absence of the appropriate substrate.

\section{DISCUSSION}

These in vitro results prompt a re-evaluation of the physiological importance of Cowper's glands, particularly in promoting rodent semen coagulation in vivo. It has been widely assumed that the only glands essential for semen coagulation in the rat are the seminal vesicles and coagulating glands, and evidence was gathered in favour of this assumption by the demonstration that simultaneous excision of both pairs of glands resulted in a failure of rat semen to coagulate (Blandau, 1945). In the absence of a coagulant, spermatozoa are not transported through the cervix to the site of fertilization and thus the mating is rendered sterile. If the coagulating glands are the only source of an enzyme capable of 
causing copulatory plug formation, their removal from a male should be as effective in promoting sterility as removing both the source of enzyme and substrate, i.e. the coagulating glands and seminal vesicles. When this hypothesis was tested, it was found that bilateral excision of the coagulating glands had no effect on fertility (Greenstein \& Hart, 1964). Moreover, the $\mathrm{pH}$ of the various glands contributing to the ejaculate in the rat is decidedly acidic, as is the vagina during oestrus (Asdell, 1964). The $\mathrm{pH}$ optimum of vesiculase is on the alkaline side (Gotterer \& Williams-Ashman, 1957) and we have observed that reducing the $\mathrm{pH}$ of the reaction to only $\mathrm{pH} 6.7$ strongly reduces its activity. Conversely, Cowper's secretion has a $\mathrm{pH}$ optimum of 5.9 and its activity is not adversely affected at a neutral $\mathrm{pH}$. These various points suggest that in the rat, mouse and hamster, Cowper's secretion plays a significant role in semen coagulation and the data serve to illustrate the biochemical complexities of the accessory products whose interactions result in the formation of the copulatory plug.

On the basis of chemical and fractionation studies, the active agent in bulbourethral secretion appears to be of high molecular weight and to be composed of a carbohydrate moiety linked, most probably, to protein. Electrophoretically, the bulbo-urethral agent responsible for vesicular coagulation in the rat displayed little migratory movement when placed in an electrical field and was identical in migration to a fraction found in mouse and hamster secretion. In both species Cowper's secretion was active in the coagulation reaction. In the guinea-pig, however, Cowper's secretion was ineffective in initiating coagulation and the fault appears to be related to an absence of an active molecule in the secretion of this species. Similarly, the migratory properties of most of the vesicular proteins from the guinea-pig differed from those of the other species studied in which the electrophoretic patterns were identical. The only vesicular protein in the guinea-pig that migrated in an identical manner to a protein found in the seminal vesicle secretion of the other species studied was Fraction III, which has been shown to be the substrate for vesiculase in the rat, mouse and guinea-pig (Mányai, 1964).

The failure of Cowper's secretion from the guinea-pig to coagulate vesicular substrate is unexpected because all species studied belong to the same order (Rodentia). However, this biochemical distinction may lend additional support to the anatomically-justified taxonomic separation of the guinea-pig into the suborder Hystricomorpha as opposed to the suborder Myomorpha containing the rat, mouse and hamster.

\section{REFERENCES}

Asdell, S. A. (1964) Patterns of mammalian reproduction, 2nd edn., p. 337. Comstock, New York.

Blandau, R. J. (1945) On the factors involved in sperm transport through the cervix uteri of the albino rat. Am. 7. Anat. 77, 253.

Camus, L. \& Gley, E. (1899) Action coagulante de liquide de la prostate externe du hérisson sur le contenu des vésicules séminales. C.r. hebd. séanc. Acad. Sci., Paris, 128, 1417.

Dische, Z. (1955) New color reactions for the determination of sugars in polysaccharides. In: Methods of Biochemical Analysis, Vol. 2, p. 313. Ed. D. Glick. Interscience, New York.

Gotterer, G. S., Ginsburg, D., Schulman, T., Banks, J. \& Williams-Ashman, H. G. (1955) Enzymatic coagulation of semen. Nature, Lond. 176, 1209. 
GotTerer, G. S. \& Williams-Ashman, H. G. (1957) Some factors which influence vesiculase action. Proc. Soc. exp. Biol. Med. 94, 60.

Greenstein, J. S. \& HART, R. G. (1964) The effects of removal of the accessory glands separately or in paired combinations on the reproductive performance of the male rat. Vth int. Congr. Anim. Reprod. Art. Insem. Trento, 3, 414.

Long, G. \& Staples, D. A. (1959) Determination of neuraminic acid in crude brain lipids. Biochem. 7 . $73,385$.

MÁNYAI, S. (1964) Isolation of the clottable protein from the secretion of the rat's seminal vesicle. Acta physiol. hung. 24, 419.

MeHL, J. W. (1945) The biuret reaction of proteins in the presence of ethylene glycol. 7. biol. Chem. $157,173$.

Speyer, J. F. (1959) Semen coagulase, a new enzyme. Fedn Proc. Fedn Am. Socs exp. Biol. 18, 150.

WALKER, G. (1910) A special function discovered in a glandular structure hitherto supposed to form a part of the prostate gland in rats and guinea-pigs. Bull. Fohns Hopkins Hosp. 21, 182.

Warburg, O. \& Christian, W. (1941) Isolierung und Kristallisation des Gärungsferments Enolase. Biochem. Z. 310, 384.

Zorgniottr, A. W. \& Brendere, H. (1958) Studies in semen coagulation. Proc. Soc. exp. Biol. Med. 96, 195. 